\title{
Firm Strategies in Open Internet of Things Business Ecosystems: Framework and Case Study
}

\author{
Anssi Smedlund \\ Aalto University \\ anssi.smedlund@aalto.fi
}

\author{
Heini Ikävalko \\ Aalto University \\ heini.ikavalko@aalto.fi
}

\author{
Petra Turkama \\ Aalto University \\ petra.turkama@aalto.fi
}

\begin{abstract}
We present a typology of strategies employed by firms using the Internet of Things (IoT). The IoT is a distributed network of connected physical objects. As these devices exchange data with each other instead of through an intermediary, the IoT increases complexity of business ecosystems, and opens up new business opportunities. When the platform owner does not own the data and technology is mostly open source, other actors can use and build on them. In addition to platform owner's strategy, we propose a framework with three additional strategies, based on whether the firms' offering integrates into the specific industrial value chain or contributes to the IoT ecosystem, and whether the firm offering is by nature stand-alone or systemic. With a multiple case study design, we explore this framework in the setting of 23 firms in a large research project context. The descriptions of the identified IoT strategies support our framework.
\end{abstract}

\section{Introduction}

Digitalization offers new opportunities that dramatically impact how organizations manage their boundaries and strategies [17, 24, 52, 65]. A business ecosystem view of the strategies is needed, because the industry is evolving towards open ecosystems from proprietary clusters and technological verticals. This transformation has been driven by elevated customer expectations and corresponding complexity in service offerings, but also by lowered cost of advanced technology and cloud computing [43].

Up until now, the winning strategy in digitalized business has been owning a platform that attracts participants and grows due to direct and indirect network effects $[42,56]$. This means that the platform owner provides a technological core that complementors can use to build on and deliver their products and services $[29,30,60]$. The platform provides complementors access to the end users resulting in a multi-sided market. Being an intermediate of the ecosystem actors generates profits for the platform owner.

The Internet of Things (IoT) increases connectivity between the actors through physical objects exchanging information in a distributed mesh. The resulting IoT system of systems is a complex adaptive system [41, 44] and it differs fundamentally from the centralized network structure forming around platforms [66].

However, the decentralized availability of data itself as a result of IoT systems does not necessarily render obsolete the benefits of platforms as basis of interaction and transaction. Instead, the now emerging IoT-driven business ecosystems allow several other strategies as well. In order to capitalize on these new emergent opportunities, dynamics of the IoT ecosystems need to be mapped, and related strategic alternatives articulated. We contribute to this understudied area of IoT by improving understanding of strategic choices specific to IoT ecosystems.

In this paper, we propose that firms may consider four archetypical strategies in the context of IoT. Owning a platform in a service system will remain strategically relevant, but there are three additional strategies: namely i) Complementor, ii) Module Producer and iii) System of Systems Facilitator. Each of these strategies allows the firm to play a distinct role in the IoT-driven business ecosystems.

We develop a framework for these strategies and argue the relevance of two dimensions: 1) the level of integration, and 2), the focus of the offering. The level of integration-dimension considers whether a firm's offering integrates into the specific industrial value chains or can be used in any context. This dimension takes into account a trend in the industry to move from value chains towards ecosystems [63]. The focus of the offering dimension describes the level of a firm's embeddedness in the business ecosystem. A standalone offering consists of either inbound or outbound knowledge processes with ecosystem actors, whereas a systemic focus involves coupled knowledge creation [c.f. , 21, 27].

We apply this framework through a multiple case study. Our cases come from two large research 
projects, which aim to advance the development of open standards for a distributed IoT ecosystem through demonstrative use cases. The firms participating in the projects represent forerunners in the IoT development and are equipped with different resources and ambitions to profit from the IoT.

This paper contributes to the emerging discussion on the management of firms in IoT ecosystems $[16,40$, 54]. It also answers a call for new frameworks to gain competitive advantage with digital technology embedded into products [67] and lays groundwork for future IoT ecosystem strategies.

\section{Related Work}

In order to establish the theoretical base for our framework, we discuss how IoT-driven business ecosystems differ from platform-driven business ecosystems by combining earlier research on digital platforms and IoT ecosystems.

\subsection{Platform-driven business ecosystems}

The term business ecosystem has been used to describe a community of interacting firms and individuals who co-evolve their capabilities and roles, and tend to align themselves with the directions set by one or more central companies [38, 49]. The central companies in the ecosystems are technology platform owners specifying shared standards and interfaces for the interdependent firms collectively providing offerings for the customer $[35,59,60]$. The technology platforms are by design onion-like multilayered structures with a non-replaceable core that is necessary for complementary technologies and services [11]. The complementors attach their offering to the platform with the combinations of technological enablers and interfaces made available by the platform owners $[10$, 31].

A platform ecosystem is a specific part of the business ecosystem consisting of a platform owner, its complementors, and end-users [8]. The growth and evolution of platform ecosystems are based on the network externalities, also often referred to as Metcalfe's law, combined with the law of increasing returns $[42,56,58]$. The offering for the end-user is a co-created, systemic value constellation, which is constructed together with the complementor and the intermediary for each end-user individually in time and place c.f., [30]. By controlling the technological core elements and access to them, the platform owner influences the growth and evolution of the platform ecosystem [33].

The processes by which platform-driven business ecosystems emerge are largely unknown, but intuitively they emerge with two archetypical mechanisms: 1) walled-garden mechanisms and 2) open mechanisms. In the walled-garden mechanism, an intermediary technology platform and the platform owner purposefully assemble a goal-oriented set of actors to create critical mass and later open the interfaces for the evolutionary growth of the platform ecosystem [29, 36]. In the open mechanism, the interfaces for end users and complementors are open and any actor can build an offering without the platform owner's consent [20,32]. Examples of the walled-garden approach include Apple's iPod and iPhone, whereas examples of open mechanisms include Linux and Google Android phone. Most other business ecosystems exhibit characteristics of both archetypes [64].

\subsection{IoT-driven business ecosystems}

IoT technologies bring about more distributed network models that challenge the prevailing logic and call for more context specific strategies and frameworks. The IoT is by general definition related to physical or virtual devices capable of sending and receiving information in real time [39]. IoT data is used in constructing a virtual counterpart of reality that can be used in optimization, prediction, safety and control $[2,16,25]$.

A practical example of how IoT data can transform a business ecosystem comes from city waste management systems. Currently, the solution providers offer sensors attached to trash bins, and point-to-point data transfer from each sensor to the server that compiles and analyzes the data to optimize waste collection logistics. An IoT application of waste management allows the sensors to be independent and connected to each other with an open standard. In the former case, a city is locked-in with a service provider with the waste management data, whereas in the latter, a city can grant access to the waste management data to anyone and there will be many companies competing for the data analysis and logistics. This competition results in potential savings to the city as not being locked-in with a single service provider.

A key point distinguishing IoT-driven business ecosystems from platform-driven business ecosystems is the extended definition of core elements. While the platform ecosystem [7] revolves around a protected technology core [31], in the IoT, the concept of a core is more complex. There are technical core elements on which the system architectures are based [61]. In addition, there are processes that are not visible to the users (e.g. many standards and data analysis methods) and front-end services for each end user individually (e.g. user interfaces and applications). Also, during the 
operation, the data from the physical connected objects accumulates in several places in the ecosystem, instead of on a centralized cloud repository at the platform. All these four elements can act as core elements in a sense that they can be opened for complementors with interfaces thus enabling others to build their extended offering based on these elements.

In IoT-driven business ecosystems, the platform owners lose their power to influence the evolution and growth of the ecosystem, but they merely orchestrate their offering-specific ecosystems, because the resources to produce the offering are not in the contractual control of the focal actor, and are mobile and distributed among the third parties [15, 57].

To sum up, in platform-driven business ecosystems, interdependencies between the actors occur either when the platform owner (i.e. the intermediator) compiles an orchestrated offering for the end user [c.f. , 51] or when firms use a single commonly accepted standard [59]. The connectivity and extended core elements that the IoT provides introduces distributed typology because of the increased interdependencies. In essence, this means that the IoT-driven inter-firm network structure is decentralized instead of centralized [34].

IoT-driven connectivity and extended core elements add to the interdependencies and transform relationships towards distributed typology with two mechanisms. Firstly, IoT devices are "smart" meaning that the devices are able to act independently as parts of systems [54]. Smartness is embedded in the control logic programmed into the devices in order to set rules on where, when, how and to whom the devices send and transmit information [22]. As the devices communicate in distributed set up, connectivity increases beyond the network intermediated by the platform owner.

Secondly, IoT devices increase linkages between several service systems that together form a system of systems. Service systems are bounded and context specific [c.f. , 37], "value configurations of people, technology, value propositions connecting internal and external service systems, and shared information" [45], although often the autonomous service systems are interconnected to a larger set of systems serving a common purpose. The resulting system of systems is a "super system", which consists of complex sub systems able to fulfill their goals even when detached from the rest of the system of systems, but reach a higher level of synergy and efficiency when attached $[34,41]$.

As smart devices transmit real world data and allow access through open standards, more firms can use the data to design their own service systems for the benefit of the end user, and even larger and more complex systems of systems will emerge. Thus the IoT takes business ecosystems towards a system of systems approach that is not under any actors control, but exhibits the qualities of complex adaptive systems: 1) evolutionary development; 2) emergent behavior; 3) self-organization; 4) adaptation; 5) complexity; 6) individual specialization; and 7) synergy [13, 34].

This differs from mechanistic, proprietary technology platform-driven business ecosystems where the platform owners maintain their brokerage positions and monetize the control advantage based on ownership of the technology and data [c.f. , 5]. The IoT makes the business ecosystem more connected and distributed, which increases complexity and makes brokerage positions harder to occupy. With this, platform focused analysis is not sufficient, but the strategies specific to IoT need to be developed.

\subsection{IoT strategy framework}

A key study classifying firms' strategies in the digital era is that of Weill and Woerner [63]. Their framework is developed for large consumer business corporations and it positions the firms in $2 \times 2$ matrix in respect to the firm's knowledge of the end customer and percentage of revenues from business ecosystem activities. This framework is a variant of Ansoff's [1] classical strategy matrix of vertical or hierarchical strategy extension, and thus provides a visual and easily communicated means for categorizing strategic orientation.

In order to accommodate the context of the IoT where firms sell their products or services to other firms in addition to consumers, we chose two dimensions as the basis of our framework: 1) firm's type of integration with either the value chain or ecosystem derived from the Weill and Woerner [63] study, and 2) firm's offering type of either stand-alone or systemic supported by the theory of open innovation (Figure 1). The value-chain type of integration means that the firm is controlling or participating in a specific value chain. Firms integrated to the ecosystem are facilitating or participating in the business ecosystem [c.f. , 51, 63]. Integration to the value chains requires tailoring, whereas integration to the ecosystem requires open interfaces for the product or service. This division is somewhat related to the dichotomy of generalists versus specialists in the studies of population ecology [26]. Both roles are needed and both have their ecological niches in the ecosystem [6]. Business ecosystems as collections of both knowledge creating value chains and actors residing outside of them [c.f., 9] implies that an ecosystem supports both types of firms thus making both strategies viable options. 
The second dimension, a stand-alone or systemic type of offering, is illustrative of how a firm is embedded in the ecosystem. Open innovation literature has established that firms engage their environment with three knowledge processes 1) outside-in, 2) inside-out and 3) coupled [21]. The outside-in and inside-out processes enable firms to benefit from either internalization of external knowledge or externalization of internal knowledge, one or the other at a time. The coupled knowledge process is about co-creation of knowledge with others by simultaneous internalization and externalization, which benefits all actors involved [27]. This distinguishes the firm in relation to the ecosystem as either systemic co-creation, resulting in systemic offering, or local stand-alone -type resulting in a firm-specific offering of products or services. Systemic solutions are known to increase the value added by the service provider [14], but they also require an orchestrator of networked resources [51]. Stand-alone offerings are also a viable strategy, the downside of less control of the ecosystem.

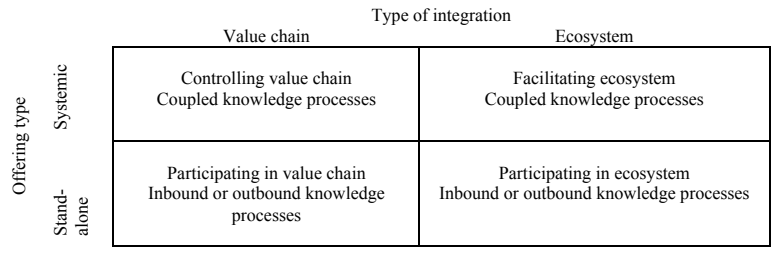

Figure 1: loT-driven business ecosystem strategies

\section{Method}

\subsection{Research design and sampling}

The research context for our study was a European Commission IoT initiative. Within this context, public funding is directed to projects considered relevant for development. Both private companies and public sector organizations, such as municipalities and universities, represent the partners of these initiatives, with both practical and scientific goals. The cases for this study are the actors of the BioTope and SyncroniCity projects. Due to our aim of developing a framework of IoT strategies, we chose a qualitative case study approach to illuminate and extend the relationships of the topic [19]. With a multiple case study design we aimed at forming "better grounded, more accurate, and more generalizable" [19] results.

Twenty-three cases were selected to represent different value chain partners in IoT ecosystems. The cases show sufficient variation in their orientation towards IoT, which would serve as theoretical sampling in this study. All the case companies shared a great interest in the IoT. As the activities and the companies operating in the field of the IoT are still scarce and struggle with value capture [47], this choice exhibits well the phenomenon of interest.

As described in the introduction, firms may orientate differently towards the IoT ecosystem. Strategic orientation refers to the guiding principles on firms' interactions with the marketplace [50], and reflects what set of actions a firm believes will lead to superior performance [28]. In order to grasp the companies' strategic orientations, we followed a narrative approach, which has proved to be a useful way of describing and understanding e.g., strategy [23] or multi-actor network processes [46]. Narratives refer to "thematic, sequenced accounts that convey meaning from implied author to implied reader" [4]. According to a narrative approach, verbal descriptions are a way of capturing the complex characterization of strategic orientations [62].

Different kinds of texts and narratives are effectively used to tell stories that communicate companies' strategic intentions [4]. Among the various mechanisms of communication, organizations communicate their strategies on the Internet. Websites provide researchers with information to evaluate firms' strategies [18]. Webpage data provide researchers with naturally occurring data [e.g. , 55] and as they are produced without the researcher's intervention, they thus act as a valuable source of information for analysis.

\subsection{Data collection}

Company websites were the primary sources of data in this paper. In order to cope with the challenges of web data collection [48], we downloaded the webpage contents for our analysis (retrieved between November 2016 and January 2017). We focused mainly on texts on the home page and on those pages where the company mission or history or other descriptions of the company's directions were described. From each case, texts from at least two pages were retrieved for analysis. To identify company characteristics such as size and industry, we used the Orbis database. As additional data source, we used project-related documents and company documentation. The role of these materials was to complement our understanding and enable us to form a rich picture of the case companies.

\subsection{Data analysis}

We undertook the analysis in three phases. First, we read through the data sources to gain an overall understanding of the companies. Secondly, we coded 
the texts. As we were interested in companies' strategic orientations towards the IoT, we considered how the texts and narrative described their goals and actions and informed their understanding of the IoT. For example, descriptions of activities characterizing and specifying products reflected an orientation towards stand-alone products. In contrast, with the systemic focus, links and connections received more attention. In terms of the level of integration, an orientation towards the value chain shows in the aim of either applying or tailoring the company solution for the customer's value chain. On the other hand, open invitations for customers' agency (e.g., by open source interface) or broad descriptions of use areas reflected an orientation towards an open ecosystem. We constructed a micro narrative of each company and captured their characteristics in the two dimensions of our framework.

In the third phase, we engaged in a cross-case analysis to associate the individual cases with the IoT positioning and to illustrate the strategic orientation types. More specifically, two researchers independently categorized the companies and positioned them according to their IoT strategy. Discussions concerning the dimensions and categorizations and rounds of iterations between data and literature led us in determining consistency of the descriptions of the strategic orientation types in the IoT framework.

\section{Findings}

The analysis of the twenty-three companies revealed that the companies are building on the emergent IoT opportunities, and developing specific strategies for their IoT offering. We found three Service System Owners, nine Complementors, six Module Producers and five System of Systems Facilitators in our data. APPENDIX 1 gives an overview of the descriptions of the case companies. The positioning of the cases in the framework revealed a set of characteristics for each strategic orientation type in the level of integration and type of offering (Table 2). Next, we will elaborate archetypes of each strategic orientation and present an example of each.

\section{Table 2: Compiled characteristics of strategic orientation types of the case companies (APPENDIX 1)}

\begin{tabular}{|l|l|l|l|l|}
\hline & $\begin{array}{c}\text { Service } \\
\text { System } \\
\text { Owner }\end{array}$ & $\begin{array}{c}\text { Compleme } \\
\text { ntor }\end{array}$ & $\begin{array}{c}\text { Module } \\
\text { Producer }\end{array}$ & $\begin{array}{l}\text { System of } \\
\text { Systems } \\
\text { Facilitator }\end{array}$ \\
\hline $\begin{array}{l}\text { Level } \\
\text { of } \\
\text { integra }\end{array}$ & $\begin{array}{l}\text { Integrates } \\
\text { with } \\
\text { physical }\end{array}$ & $\begin{array}{l}\text { Integrates } \\
\text { and } \\
\text { complement }\end{array}$ & $\begin{array}{l}\text { Integrates } \\
\text { with any }\end{array}$ & $\begin{array}{l}\text { Open } \\
\text { globally or } \\
\text { regionally }\end{array}$ \\
\hline
\end{tabular}

\begin{tabular}{|c|c|c|c|c|}
\hline tion & $\begin{array}{l}\text { infrastructu } \\
\text { re and } \\
\text { informatio } \\
\mathrm{n} \text { systems } \\
\text { of end- } \\
\text { users and } \\
\text { compleme } \\
\text { ntors }\end{array}$ & $\begin{array}{l}\mathrm{s} \text { client- } \\
\text { specific } \\
\text { business } \\
\text { model and } \\
\text { services }\end{array}$ & $\begin{array}{l}\text { business } \\
\text { model } \\
\text { and } \\
\text { services } \\
\text { in off-the- } \\
\text { shelf } \\
\text { fashion }\end{array}$ & for anyone \\
\hline $\begin{array}{l}\text { Offeri } \\
\mathrm{ng} \\
\text { focus }\end{array}$ & $\begin{array}{l}\text { User } \\
\text { experience } \\
\text { (UX) } \\
\text { driven } \\
\text { value } \\
\text { proposition } \\
\text { for end- } \\
\text { users } \\
\text { implement } \\
\text { ed with } \\
\text { bounded } \\
\text { set of } \\
\text { compleme } \\
\text { ntors }\end{array}$ & $\begin{array}{l}\text { Tailored- } \\
\text { or stand- } \\
\text { alone } \\
\text { service } \\
\text { intensive } \\
\text { solutions for } \\
\text { specific } \\
\text { industries }\end{array}$ & $\begin{array}{l}\text { Technolo } \\
\text { gy, } \\
\text { product or } \\
\text { a ready- } \\
\text { made } \\
\text { solution } \\
\text { developed } \\
\text { by the } \\
\text { firm }\end{array}$ & $\begin{array}{l}\text { Maintainin } \\
\mathrm{g} \\
\text { standards, } \\
\text { acting as } \\
\text { trusted } \\
\text { collaborato } \\
\mathrm{r} \text { in IoT } \\
\text { business } \\
\text { and } \\
\text { facilitator } \\
\text { of research } \\
\text { and } \\
\text { developme } \\
\mathrm{nt}\end{array}$ \\
\hline $\begin{array}{l}\text { Numb } \\
\text { er of } \\
\text { cases } \\
\text { in the } \\
\text { sample }\end{array}$ & 3 & 9 & 6 & 5 \\
\hline
\end{tabular}

In the Service System Owner strategy, a firm operates in a closed or semi-closed proprietary system or controlled set of standards and with a bounded set of actors, of which some are contractually bound to the platform owner. The owner controls some of the partners and aims to control the growth and evolution path of the resulting service system or system of systems. The scope of operations is clear and focused on a specific value chain or a use case. The business model is to profit from the end users, or if the service system is a multi-sided market, to profit from all participants. This strategy is focused and applicable to early introduction and growth stages, and can be later scaled to system of systems facilitator strategy with extensions from other industries.

In our data, three of the case companies represented this type. For example, one of these, $B M W$ acts as a traditional proprietary platform owner in their ecosystems of IoT solutions enhancing the experience of operating a motor vehicle. By acting in this role, they increase the connectivity and service offering of the ecosystem. The platform owner sets the criteria for the ecosystem companies, and specifies the terms of engagement. The platform owner acts as a central node in the ecosystem, resulting in a centralized network structure. Collaboration is relationship based and can follow loose-orchestration-type models, or more rigid management models. As the profit comes from the end users, their involvement as users of the services is crucial.

In a Complementor strategy, firms sell tailored services or service intensive products through service 
systems owned by other companies or channels specific to a certain use case area, standard or a value chain. In this role the firms control over the system is limited, and the firm is reactive to requirements and changes, rather than proactive. The complementors usually have fixed contracts with the platform owners, and are not able to directly apply one solution to another context. The business model is to profit from the sales of professional services that result from the Complementor tailoring and maintaining its solution in the service system, as well as through services. Through the platform owner, the Complementor enjoys network externalities, and can reach new markets, customers, and service constellations. The risk is limited and the products typically standardized, and developed to the platform owners' interface without shared processes or visibility of the owners' systems. This strategy can be preferable for small organizations, and can be scaled to module producer strategy with the application of open interfaces.

In our study, this type was the most typical strategic orientation within the case companies. Altogether eight case companies were interpreted as Complementors. For example, Enervent, which supplies smart metering equipment and other IoT hardware for smart home use cases, can be identified as a Complementor. It offers stand-alone products for ventilation, but also earns profits from services related to the product. A typical Complementor offers a higher level of specialization and niche offering. Firms representing this type share the character of providing tailored services or products and aim to profit from connecting their products to service systems.

In a Module Producer strategy, firms produce solutions that are interoperable and can be integrated into all kinds of technology platforms and service systems through a standardized interface. Module Producer has little control over the service system orchestration. Modules are stand-alone solutions, for example, software to increase the speed of connectivity between devices in a smart home that is then integrated into a device or software product. The business model aims at collecting royalties from the sales of the end product or service. Module producers business model builds on scale economics, and the product lifecycles are typically limited. Module producers typically operate in open ecosystems and the relationship with the platform owner is transactional. In our data, seven companies represented this type. They typically benefit from flexibility and mass customization. A typical example of a Module Producer is Holonix, which offers solutions for product lifecycle knowledge management. Their stand-alone solutions can be integrated into any ecosystem, and thus extend the product lifetime.
A System of Systems Facilitator controls and defines interface standards that connect different independent technology platforms, typically on the API level. The companies loosely collaborate. There are joint offerings, but collaboration is more ad hoc orchestrated than actually managed. Partners pay rents to the Facilitator and benefit from the network externalities and opportunities to scale. A typical business model is non-profit, and the facilitator collects membership fees from the ecosystem participants and provides professional services for firms to educate participants to use the open standards it maintains. The ecosystem evolves in emergent fashion and the participants benefit from emerging innovation opportunities. Five of the case companies in our study had a System-of-System Facilitator orientation. For example, Opengroup, a consortium of hundreds of member organizations, enables others' connectivity in the ecosystem. They provide a platform for others to perform on and try to make their performance easier by co-creating shared rules and boundaries for performance.

\section{Discussion}

The goal of this paper was to explicate firm strategies in IoT-driven business ecosystems. Our analysis was a multiple case study of firms participating in two large research projects. Firstly, we examined the narratives that the firms provide on their webpages in order to determine their strategic orientations. Secondly, we positioned the firms in the strategy framework we created. Based on the increased connectivity that IoT provides as well as processes and data as core elements, IoT business ecosystems resemble complex adaptive systems that allow more diverse strategies in addition to owning a technology platform. Based on our framework, the firms can be distinguished from each other with their types of integration to the value chains and standalone versus systemic offering focus.

Our results indicate that firms have started to develop specific IoT strategies that differ from their dominant product strategies. In some cases the strategy was still pursuing the traditional product logic, but some companies have developed specific offerings for the IoT business ecosystems, and leveraged emergent opportunities through increased connectivity. The participating companies could be clearly divided into the categories of Module Producers, Complementors, Service System Owners or System of Systems Facilitators. Understanding the characteristics, terms and limitations of each strategy will increase a firm's awareness of the opportunities and evolutionary paths for each chosen strategy. 


\subsection{Theoretical contribution}

Our study contributes to the emerging IoT management research $[16,40,54]$ by integrating theory from technology platforms, service science, and systems theory. Despite its rapid growth and industrial relevance, IoT business research is still in an embryonic state. Our study is the first in which firm strategies are approached from an IoT point of view. The strength of our paper is in its explaining foreseeable change that the IoT induces in the fundaments of the business ecosystems, and in coining future business ecosystems as systems of systems, complex adaptive systems [c.f. , 41], and appreciating the different strategies for various network actors. The second strength of our study is in providing a framework to classify firm strategies in the IoT context. By doing so, we add to the discussion began by Weill and Woerner [63] on digital strategies.

Our study also extends open innovation research as we draw justification for our framework from the three knowledge processes [21]. As most studies have focused on open innovation from a standalone (i.e. outside-in or inside-out knowledge processes) point of view [12], our framework and results support the notion of Gassman et al. [27] that technology and offerings are becoming so complex that firms are unable to develop them by themselves, highlighting the need for coupled knowledge processes. However, as our framework implies, a strategy based on standalone processes remains viable, as firms can play complementor or modular producer roles in the business ecosystem.

\subsection{Limitations and further research}

Despite its contributions, this study has limitations, which provide ground for further research. The cases were selected from two research projects, and it is unclear as to whether the firms outside of the projects can be classified with our methodology. However, the firms are very well established in the market and have strong businesses in addition to participating in publicly funded projects. Furthermore, studies in population ecology [53] assume that firms imitate each others strategic orientations. Thus we have grounds to expect that the studied firms somewhat reflect the archetypical types of the respective industries.

Future research could extend the findings of this paper in numerous ways and through a variety of methods. As website analysis provides an initial positioning of the firms, conducting interviews or questionnaires would increase the reliability of the results and provide in-depth knowledge of our topic. Also performing a longitudinal study on the explicated strategies would capture the dynamics of IoT strategies. Following population ecology arguments, we can hypothesize that firms with similar strategic orientations become more alike over time, which can reveal the structures and sources of competitive advantage of the underlying business ecosystem. It would be relevant to study how firm strategies change as new technology enables increased connectivity, and what strategic directions firms take in the different maturity stages of that technology.

\subsection{Managerial implications}

The extant understanding of the competition in a business ecosystem is that competition is increasingly taking place between the platform ecosystems (i.e. networks of complementors and end users intermediated by the platform owner), and not so much between individual firms [56]. Our paper suggests that in order to capture value from the IoT-driven business ecosystem, firms must be able to establish and sustain their presence as Service System Owners, Complementors, Module Producers or System of Systems Facilitators. Most firms are not born into these roles, but the roles have evolved over time. As connectivity increases along with processes and data as core elements in addition to technology, the competitive advantage will be found in managing the complexity through increased specialization and with a value proposition that shows substantial value for the end users. Despite that our research context is the IoT, our framework can be used in strategizing digital business in general.

Our framework is illustrative for policymakers, as it can be used as a normative tool to evaluate the roles of organizations in IoT-driven ecosystems. The framework implies that all roles are valuable, and firms can change their roles over time. Also, firms or organizations may play several roles simultaneously. As the IoT is a rapidly growing phenomenon that may have positive and negative societal impacts, regulators should pay close attention to what roles different actors play and how. Our framework may be thus used in creating IoT ecosystems in public-private partnerships and public services.

\subsection{Conclusion}

Contributing to the emerging field of business research in the Internet of Things (IoT) context, in this paper, we examined different firm strategies in IoTdriven business ecosystems. Our typology reduces complexity and describes archetypical strategies. These strategies will further classify applicable orchestration and contract types, and ease business model planning. 
The results suggest that the framework is applicable and useful for corporate and policy planning purposes. With our ecosystem typology of IoT strategies, we can better define roles for each actor in the ecosystem and understand the different sources of competitive advantage.

\section{Acknowledgements}

The bIoTope and SyncroniCity projects and this research have received funding from the European Commission.

\section{References}

[1] Ansoff, H.I., "Strategic issue management", Strategic Management Journal 1(2), 1980, pp. 131-148.

[2] Atzori, L., A. Iera, and G. Morabito, "Understanding the Internet of Things: definition, potentials, and societal role of a fast evolving paradigm", Ad Hoc Networks 56, 2017, pp. $122-140$.

[3] Barabási, A.-L., Linked: the New Science of Networks, Perseus Publishing, Cambridge (MA), 2002.

[4] Barry, D., and M. Elmes, "Strategy retold: Toward a narrative view of strategic discourse", Academy of Management Review 22(2), 1997, pp. 429-452.

[5] Burt, R.S., The Social Structure of Competition, Harvard University Press, Cambridge, Mass., 1992.

[6] Carroll, G.R., and A. Swaminathan, "Why the Microbrewery Movement? Organizational Dynamics of Resource Partitioning in the U.S. Brewing Industry", American Journal of Sociology 106(3), 2000, pp. 715-762.

[7] Ceccagnoli, M., and C. Forman, "Cocreation of Value in a Platform Ecosystem: The Case of Enterprise Software", MIS Quarterly 36(1), 2012, pp. 263-290.

[8] Ceccagnoli, M., C. Forman, P. Huang, and D.J. Wu, "Cocreation of value in a platform ecosystem: The case of enterprise software", MIS Quarterly 36(1), 2012, pp. $263-$ 290.

[9] Clarysse, B., M. Wright, J. Bruneel, and A. Mahajan, "Creating value in ecosystems: Crossing the chasm between knowledge and business ecosystems", Research Policy 43(7), 2014, pp. 1164-1176.

[10] Cusumano, M., "Technology strategy and managementThe evolution of platform thinking", Communications of the ACM 53(1), 2010, pp. 32.

[11] Cusumano, M.A., and A. Gawer, "The Elements of Platform Leadership", MIT Sloan Management Review 43(3), 2002, pp. 51-58.

[12] Dahlander, L., and D.M. Gann, "How open is innovation?", Research Policy 39(6), 2010, pp. 699-709.

[13] Darabi, H.R., "The role of competition and collaboration in influencing the level of autonomy and belonging in system of systems", IEEE Systems Journal 7(4), 2013, pp. 520-527.

[14] Davies, A., "Moving base into high-value integrated solutions: a value stream approach", Industrial \& Corporate Change 13(5), 2004, pp. 727-756.

[15] Dhanaraj, C., and A. Parkhe, "Orchestrating Innovation Networks", Academy of Management Review 31(3), 2006, pp. 659-669.
[16] Dijkman, R.M., B. Sprenkels, T. Peeters, and A. Janssen, "Business models for the Internet of Things", International Journal of Information Management 35(6), 2015, pp. 672-678.

[17] Dougherty, D., and D.D. Dunne, "Digital Science and Knowledge Boundaries in Complex Innovation", Organization Science 23(5), 2012, pp. 1467-1484.

[18] Ebben, J.J., and A.C. Johnson, "Efficiency, flexibility, or both? Evidence linking strategy to performance in small firms", Strategic Management Journal 26(13), 2005, pp. 1249-1259.

[19] Eisenhardt, K.M., and M.E. Graebner, "Theory building from cases: Opportunities and challenges", Academy of Management Journal 50(1), 2007, pp. 25-32.

[20] Eisenmann, T.R., G. Parker, and M. Van Alstyne, "Opening Platforms: How, When and Why?", Harvard Business School working papers 09-030, 2008.

[21] Enkel, E., O. Gassmann, and H. Chesbrough, "Open R\&D and open innovation: Exploring the phenomenon", $R$ and D Management 39, 2009, 311-316.

[22] Espinha, T., A. Zaidman, and H.G. Gross, "Web API growing pains: Loosely coupled yet strongly tied", Journal of Systems and Software 100, 2015, pp. 27-43.

[23] Fenton, C., and A. Langley, "Strategy as Practice and the narrative turn", Organization Studies 32(9), 2011, pp. 1171-1196.

[24] Fitzgerald, M., N. Kruschwitz, D. Bonnet, and M. Welch, "Embracing Digital Technology: A New Strategic Imperative", MIT Sloan Management Review, 2013, pp. 112.

[25] Främling, K., J. Holmström, T. Ala-Risku, and M. Kärkkäinen, "Product agents for handling information about physical objects", Report of Laboratory of information processing science series $B$, TKO-B, 153(03)., 2003.

[26] Freeman, J., and M.T. Hannan, "Niche Width and the Dynamics of Organizational Populations", American Journal of Sociology 88(6), 1983, pp. 1116.

[27] Gassmann, O., E. Enkel, and H. Chesbrough, "The future of open innovation", $R$ and D Management 40, 2010, 213-221.

[28] Gatignon, H., and J.-M. Xuereb, "Strategic orientation of the firm and new product performance", Journal of Marketing Research 34(February), 1997, pp. 77-90.

[29] Gawer, A., "Bridging differing perspectives on technological platforms: Toward an integrative framework", Research Policy 43, 2014, pp. 1239-1249.

[30] Gawer, A., and M.A. Cusumano, Platform Leadership: How Intel, Microsoft, and Cisco Drive Industry Innovation, Harvard Business School Press, Boston, 2002.

[31] Gawer, A., and M.A. Cusumano, "How companies become platform leaders", MIT Sloan Management Review 49(2), 2008, pp. 28-35.

[32] Gawer, A., and R. Henderson, "Platform owner entry and innovation in complementary markets: Evidence from Intel", Journal of Economics \& Management Strategy 16(1), 2007, pp. 1-34.

[33] Ghazawneh, A., and O. Henfridsson, "Balancing platform control and external contribution in third-party development: The boundary resources model", Information Systems Journal 23(2), 2013, pp. 173-192. 
[34] Gorod, A., B. Sauser, and J. Boardman, "System-ofSystems Engineering Management: A Review of Modern History and a Path Forward", IEEE Systems Journal 2(4), 2008, pp. 484-499.

[35] Hagiu, A., and J. Wright, "Multi-sided platforms", International Journal of Industrial Organization 43, 2015, pp. 162-174.

[36] Hazlett, T.W., D.J. Teece, and L. Waverman, "Walled garden rivalry: the creation of mobile network ecosystems", George Mason Law and Economics Research Paper No. 11$50,2011$.

[37] Hessami, A., "A framework for characterising complex systems and system of systems", Proceedings - 2013 IEEE International Conference on Systems, Man, and Cybernetics, SMC 2013, 2013, pp. 1702-1708.

[38] Iansiti, M., and R. Levien, "Strategy as ecology", Harvard Business Review 82(3), 2004, pp. 68-78.

[39] International Telecommunication Union (ITU), "Series Y: Global information infrastructure, internet protocol aspects and next-generation networks - Frameworks and functional architecture models: Overview of the Internet of things", ITU-T: Telecommunication Standardization Sector of ITU Y.2060, 2012, pp. 1-22.

[40] Ju, J., M.-S. Kim, and J.-H. Ahn, "Prototyping Business Models for IoT Service", Procedia Computer Science 91(Itqm), 2016, pp. 882-890.

[41] Karcanias, N., and A.G. Hessami, "Complexity and the notion of system of systems: Parts (I\&II)", World Automation Congress (WAC), 2010 (Ii), 2010, pp. 1-7.

[42] Katz, M.L., and C. Shapiro, "Systems Competition and Network Effects", Journal of Economic Perspectives 8(2), 1994, pp. 93-115.

[43] Kushida, K.E., J. Murray, and J. Zysman, "Cloud Computing: From Scarcity to Abundance", Journal of Industry, Competition and Trade 15(1), 2015, pp. 5-19.

[44] Li, S., L. Da Xu, and S. Zhao, "The internet of things: a survey", Information Systems Frontiers 17(2), 2015, pp. 243-259.

[45] Maglio, P.P., and J. Spohrer, "Fundamentals of service science", Journal of the Academy of Marketing Science 36(1), 2008, pp. 18-20.

[46] Makkonen, H., L. Aarikka-Stenroos, and R. Olkkonen, "Narrative approach in business network process research Implications for theory and methodology", Industrial Marketing Management 41(2), 2012, pp. 287-299.

[47] Manyika, J., M. Chui, P. Bisson, et al., "The Internet of Things: Mapping the value beyond the hype", McKinsey Global Institute(June), 2015, pp. 144.

[48] McMillan, S.J., "The Microscope and the Moving Target: The Challenge of Applying Content Analysis to the World Wide Web", Journalism \& Mass Communication Quarterly 77(1), 2000, pp. 80-98.

[49] Moore, J.F., "Predators and prey: a new ecology of competition.", Harvard Business Review 71(3), 1993, pp. 7586.

[50] Noble, C.H., R.K. Sinha, and A. Kumar, "Market Orientation and Alternative Strategic Orientations: A Longitudinal Assessment of Performance Implications", Journal of Marketing 66(4), 2002, pp. 25-39.
[51] Normann, R., and R. Ramirez, "From value chain to value constellation: Designing interactive strategy", Harvard Business Review 71(4), 1993, pp. 39-51.

[52] Parker, G., M. Van Alstyne, and X. Jiang, "Platform Ecosystems: How Developers Invert the Firm", MIS Quarterly 41(1), 2017, pp. 255-266.

[53] Podolny, J.M., T. Stuart, and M.T. Hannan, Niches, Knowledge, and Networks: Competition in the Worldwide Semiconductor Industry, 1984-1991, Stanford University, 1996.

[54] Porter, M.E., and J.E. Heppelmann, "How smart, connected products are transforming companies", Harvard Business Review 2015, 2015, 64-89.

[55] Potter, J., "Discourse Analysis as a Way of Analysing Naturally Occurring talk", In Qualitative Research: Theory, Method and Practice. Sage, London, 1997.

[56] Shapiro, C., and H. Varian, Information rules. A strategic guide to the network economy., Harvard Business School Press, Boston, 1999.

[57] Smedlund, A., and H. Faghankhani, "Platform Orchestration for Efficiency, Development and Innovation", 48th Hawaii International Conference on System Sciences (HICSS 2015), (2015).

[58] Teece, D., "Capturing Value from Knowledge Assets: The New Economy, Markets for Knowhow and Intatngible Assets", California management review 40(3), 1998, pp. 5579.

[59] Teece, D.J., "Business Ecosystem", The Palgrave Encyclopedia of Strategic Management, 2014.

[60] Tiwana, A., Platform Ecosystems: Aligning Architecture, Governance, and Strategy, Morgan Kaufmann, Waltham, MA, 2014.

[61] Tiwana, A., B. Konsynski, and A.A. Bush, "Platform evolution: Coevolution of platform architecture, governance, and environmental dynamics", Information Systems Research 21, 2010, pp. 675-687.

[62] Venkatraman, N., "The concept of fit in strategy research: Toward verbal and statistical correspondence", Academy of Management Review 14(3), 1989, pp. 423-444.

[63] Weill, P., and S.L. Woerner, "Thriving in an Increasingly Digital Ecosystem", MIT Sloan Management Review 56(4), 2015, pp. 27-34.

[64] West, J., "The Economic Realities of Open Standards: Black, White and Many Shades of Gray", In Standards and Public Policy. 2007, 87-122.

[65] Whelan, E., R. Teigland, B. Donnellan, and W. Golden, "How internet technologies impact information flows in R\&D: Reconsidering the technological gatekeeper", $R$ and $D$ Management 40(4), 2010, pp. 400-413.

[66] Wu, Q., G. Ding, Y. Xu, et al., "Cognitive Internet of Things: A New Paradigm Beyond Connection", IEEE Internet of Things Journal 1(2), 2014, pp. 129-143.

[67] Yoo, Y., O. Henfridsson, and K. Lyytinen, "The New Organizing Logic of Digital Innovation: An Agenda for Information Systems Research", Information Systems Research 21(4), 2010, pp. 724-735. 


\section{Appendix 1: Descriptions of the studied companies}

\begin{tabular}{|c|c|c|c|c|c|c|c|}
\hline Company & Offering focus & $\begin{array}{l}\text { Stand- } \\
\text { alone }\end{array}$ & $\begin{array}{c}\text { Syste } \\
\text { mic }\end{array}$ & Level of integration & $\begin{array}{l}\text { Value } \\
\text { chain }\end{array}$ & $\begin{array}{c}\text { Eco- } \\
\text { system }\end{array}$ & $\begin{array}{l}\text { Strat.o } \\
\text { rient. }\end{array}$ \\
\hline $\begin{array}{l}B M W \text {, a global manufacturer of automobiles and } \\
\text { motorcycles }\end{array}$ & $\begin{array}{l}\text { Offers services in closed system with limited set of } \\
\text { actors. }\end{array}$ & & $\mathrm{x}$ & $\begin{array}{l}\text { Customers offered services in } \\
\text { driving-related value chain }\end{array}$ & $\mathrm{x}$ & & SSO \\
\hline $\begin{array}{l}\text { Cityzen Data, platform provider for sports, health } \\
\text { and wellness markets }\end{array}$ & Offers technology for sensor data management & $\mathrm{x}$ & & $\begin{array}{l}\text { Scalable platform enables } \\
\text { adaptability to any ecosystem }\end{array}$ & & $\mathrm{x}$ & MP \\
\hline $\begin{array}{l}\text { ControlThings, a start-up with a software for data } \\
\text { acquisition from sensing devices }\end{array}$ & Offers stand-alone IoT technology product & $\mathrm{x}$ & & $\begin{array}{l}\text { Can be integrated with products, } \\
\text { apps or other systems. }\end{array}$ & & $\mathrm{x}$ & MP \\
\hline $\begin{array}{l}\text { Eccenca, a spin-off focusing on scientific } \\
\text { excellence and translation of technology in } \\
\text { sustainable, marketable solutions }\end{array}$ & $\begin{array}{l}\text { Offers stand-alone semantic big data management } \\
\text { products }\end{array}$ & $\mathrm{x}$ & & $\begin{array}{l}\text { Banking and manufacturing value } \\
\text { chains }\end{array}$ & $\mathrm{x}$ & & $\mathrm{C}$ \\
\hline $\begin{array}{l}\text { Enervent, a medium-size company aiming at better } \\
\text { indoor climate with their products }\end{array}$ & $\begin{array}{l}\text { Offers stand-alone products for energy efficiency } \\
\text { and heat-recovery in ventilation }\end{array}$ & $\mathrm{x}$ & & Construction value chain & $\mathrm{x}$ & & $\mathrm{C}$ \\
\hline $\begin{array}{l}\text { Holonix, a spin-off providing solutions based on } \\
\text { research conducted by university researchers }\end{array}$ & $\begin{array}{l}\text { Offers products and services for lifecycle data and } \\
\text { knowledge management }\end{array}$ & $\mathrm{x}$ & & Modular solution for all sectors & & $\mathrm{x}$ & MP \\
\hline $\begin{array}{l}\text { Irisnet, a telecom operator of a regional network, } \\
\text { with a strong relationship with a major national } \\
\text { telecom operator }\end{array}$ & Provides services in a controlled local environment & & $\mathrm{x}$ & $\begin{array}{l}\text { Offers services in a telecom value } \\
\text { chain }\end{array}$ & $\mathrm{x}$ & & SSO \\
\hline $\begin{array}{l}\text { Itrust consulting, a consulting company for public, } \\
\text { financial and industrial customers }\end{array}$ & Offers information security system services & $\mathrm{x}$ & & In the area of Information security & $\mathrm{x}$ & & $\mathrm{C}$ \\
\hline $\begin{array}{l}\text { OpenDataSoft, an international software as-a- } \\
\text { service provider }\end{array}$ & $\begin{array}{l}\text { Provides an open-source front end for data } \\
\text { management }\end{array}$ & & $\mathrm{x}$ & $\begin{array}{l}\text { Enables creation of collaborative } \\
\text { ecosystems, emphasizes co- } \\
\text { creation and empowerment }\end{array}$ & & $\mathrm{x}$ & SSF \\
\hline $\begin{array}{llr}\text { The Open } & \text { Group, a consortium of hundreds of } \\
\text { member organizations representing, e.g. } \\
\text { customers, system and solution supplier, tool } \\
\text { vendors, consultants and researchers }\end{array}$ & $\begin{array}{l}\text { Provides vendor-neutral forum for IT standards and } \\
\text { certifications }\end{array}$ & & $\mathrm{x}$ & $\begin{array}{l}\text { Drives an open source } \\
\text { development in all sectors of IT } \\
\text { community }\end{array}$ & & $\mathrm{x}$ & SSF \\
\hline $\begin{array}{l}\text { Atos, large company in digital services, strives to } \\
\text { act as trusted partner for its clients }\end{array}$ & $\begin{array}{l}\text { Provides total solutions based on client needs with } \\
\text { wide expertise in many areas }\end{array}$ & $\mathrm{x}$ & & $\begin{array}{l}\text { Integrates to given context of } \\
\text { client }\end{array}$ & $\mathrm{x}$ & & $\mathrm{C}$ \\
\hline $\begin{array}{l}\text { BronzeLabs, a software company specializing in } \\
\text { IoT application development for smart cities }\end{array}$ & Technology used in data connections & $\mathrm{x}$ & & $\begin{array}{l}\text { Can be integrated with any context } \\
\text { where applicable }\end{array}$ & & $\mathrm{x}$ & MP \\
\hline $\begin{array}{l}\text { Engineering Ingegneria Informatica } S p A \text {, software } \\
\text { and IT-services company }\end{array}$ & $\begin{array}{l}\text { Professional services to be tailored according to } \\
\text { client needs in any market }\end{array}$ & $\mathrm{x}$ & & $\begin{array}{l}\text { Complements client-specific } \\
\text { business model and services }\end{array}$ & $\mathrm{x}$ & & $\mathrm{C}$ \\
\hline $\begin{array}{l}\text { Heijmans Wegen } B V \text {, a company providing know- } \\
\text { how and concepts in construction industry }\end{array}$ & $\begin{array}{l}\text { Ideas and solutions as a service to create added } \\
\text { value for clients }\end{array}$ & $\mathrm{x}$ & & $\begin{array}{l}\text { Focuses on building-related value } \\
\text { chains }\end{array}$ & $\mathrm{x}$ & & $\mathrm{C}$ \\
\hline $\begin{array}{l}\text { Philips Lighting B.V., a large industrial company, } \\
\text { acts as orchestrator in ecosystem, aiming at } \\
\text { endless connectivity and offering services } \\
\text { integrated with physical infrastructures. }\end{array}$ & $\begin{array}{l}\text { User experience-based value proposition for end- } \\
\text { users though offering is targeted for b-to-b clients }\end{array}$ & & $\mathrm{x}$ & $\begin{array}{l}\text { Integrates with physical } \\
\text { infrastructures in public spaces, } \\
\text { retail, industry and hospitality }\end{array}$ & $\mathrm{x}$ & & SSO \\
\hline Rombit, a small IoT solutions company & $\begin{array}{l}\text { Analysis of client's ICT systems connectivity and } \\
\text { then offers analytics of systems through mobile } \\
\text { devices }\end{array}$ & $\mathrm{x}$ & & $\begin{array}{l}\text { Integrates with client-specific } \\
\text { offering }\end{array}$ & $\mathrm{x}$ & & $\mathrm{C}$ \\
\hline $\begin{array}{l}\text { Telefónica Investigación y Desarrollo SAU, } \\
\text { innovation-focused company contributing to its } \\
\text { parent company's success }\end{array}$ & $\begin{array}{l}\text { Develops applications from idea to product. } \\
\text { Applications are then used as parts of parent } \\
\text { company's systems, and also offered to other } \\
\text { clients. }\end{array}$ & $\mathrm{x}$ & & $\begin{array}{l}\text { The offering is a set of stand-alone } \\
\text { software products }\end{array}$ & & $\mathrm{x}$ & $\mathrm{C}$ \\
\hline $\begin{array}{l}\text { Tecnologías, Servicios Telemáticos y Sistemas, a } \\
\text { small company in data transfer }\end{array}$ & $\begin{array}{l}\text { Develops customized products and solutions to be } \\
\text { used in cloud data transfer }\end{array}$ & $\mathrm{x}$ & & $\begin{array}{l}\text { Solutions are tailored to each } \\
\text { customer's needs by TeSco }\end{array}$ & $\mathrm{x}$ & & $\mathrm{C}$ \\
\hline $\begin{array}{l}\text { Ubiwhere ("UBI"), a company serving smart city } \\
\text { needs with their innovation process for companies } \\
\text { IoT development }\end{array}$ & $\begin{array}{l}\text { Offers portfolio of ready made solutions that solve } \\
\text { problems in IoT context }\end{array}$ & $\mathrm{x}$ & & $\begin{array}{l}\text { Can integrate with any smart city } \\
\text { context }\end{array}$ & & $\mathrm{x}$ & MP \\
\hline $\begin{array}{l}\text { HOP Ubiquitous ("HOPU"), a company in IoT } \\
\text { connectivity and management }\end{array}$ & $\begin{array}{l}\text { Offers chipsets and sensor combinations as well as } \\
\text { services related to them. }\end{array}$ & $\mathrm{x}$ & & Can be used in any IoT context & & $\mathrm{x}$ & MP \\
\hline $\begin{array}{l}\text { Mandat International ("MI"), a foundation that } \\
\text { encourages dialogue and cooperation within an } \\
\text { international network. }\end{array}$ & $\begin{array}{l}\text { Offers online tools, organizes conferences, sets up } \\
\text { development projects }\end{array}$ & & $\mathrm{x}$ & $\begin{array}{l}\text { Maintain foundation whose } \\
\text { membership is open to anyone }\end{array}$ & & $\mathrm{x}$ & SSF \\
\hline $\begin{array}{l}U D G \text { Alliance ("UDG"), alliance around a control } \\
\text { and monitoring system set up as shared effort of } \\
\text { partnering organizations }\end{array}$ & $\begin{array}{l}\text { Supports research activities in addition to } \\
\text { maintaining standards related to framework }\end{array}$ & & $\mathrm{x}$ & $\begin{array}{l}\text { Alliance open for all who wish to } \\
\text { use the framework they maintain }\end{array}$ & & $\mathrm{x}$ & SSF \\
\hline $\begin{array}{l}\text { Digital Catapult ("DigiCat"), operates in a } \\
\text { specific geographic area and serves firms and } \\
\text { public organizations by involving them in } \\
\text { collaborative programs and open innovation. }\end{array}$ & $\begin{array}{l}\text { Supports digital businesses and employees in } \\
\text { digital work roles. Applied research and } \\
\text { development collaboration }\end{array}$ & & $\mathrm{x}$ & $\begin{array}{l}\text { Open for UK digital ecosystem } \\
\text { actors }\end{array}$ & & $\mathrm{x}$ & SSF \\
\hline
\end{tabular}

